\title{
Activation of Presynaptic 5-Hydroxytryptamine 2A Receptors Facilitates Excitatory Synaptic Transmission via Protein Kinase C in the Dorsolateral Septal Nucleus
}

\author{
Hiroshi Hasuo, ${ }^{1}$ Toshimasa Matsuoka, ${ }^{1,2}$ and Takashi Akasu ${ }^{1}$ \\ Departments of ${ }^{1}$ Physiology and ${ }^{2}$ Neuropsychiatry, Kurume University School of Medicine, Kurume 830-0011, Japan
}

\begin{abstract}
Effects of 5-hydroxytryptamine (5-HT) on EPSPs and EPSCs in the rat dorsolateral septal nucleus (DLSN) were examined in the presence of $\mathrm{GABA}_{A}$ and $\mathrm{GABA}_{B}$ receptor antagonists. Bath application of 5-HT $(10 \mu \mathrm{M})$ for $5-10$ min increased the amplitude of the EPSP and EPSC. ( \pm )-8-Hydroxy-2-(di-N-propylamino)tetralin hydrobromide $(10 \mu \mathrm{M})$, an agonist for $5-\mathrm{HT}_{1 \mathrm{~A}}$ and $5-\mathrm{HT}_{7}$ receptors, did not facilitate the EPSP. $\alpha$-Methyl-5-HT $(10 \mu \mathrm{M})$, a $5-\mathrm{HT}_{2}$ receptor agonist, increased the amplitude of the EPSC. $\alpha$-Methyl-5-(2thienylmethoxy)-1H-indole-3-ethanamine $(10 \mu \mathrm{M})$ and 6-chloro-2(1-piperazinyl)pyrazine $(10 \mu \mathrm{M})$, selective $5-\mathrm{HT}_{2 \mathrm{~B}}$ and $5-\mathrm{HT}_{2 \mathrm{C}}$ receptor agonists, respectively, had no effect on the EPSP. The 5-HT-induced facilitation of the EPSP was blocked by ketanserin $(10 \mu \mathrm{M})$, a $5-\mathrm{HT}_{2 \mathrm{~A} / 2 \mathrm{C}}$ receptor antagonist. However, $\mathrm{N}$-desmethylclozapine $(10 \mu \mathrm{M})$, a selective $5-\mathrm{HT}_{2 \mathrm{C}}$ receptor antagonist, did not block the facilitation of the EPSP induced by $\alpha$-methyl-5-HT. The inward current evoked by exogenous glutamate was unaffected
\end{abstract}

Principal neurons in the dorsolateral septal nucleus (DLSN) receive glutamatergic nerve axons from the hippocampal CA1 and CA3 regions via the fimbria-fornix pathway and send axons to hypothalamic and amygdaloid areas (Alonso and Frotscher, 1989; Gallagher et al., 1995; Jakab and Leranth, 1995). Stimulation of the fimbria-fornix pathway evokes EPSPs followed by IPSPs in DLSN neurons (Alonso and Frotscher, 1989; Gallagher et al., 1995; Jakab and Leranth, 1995). DLSN neurons also receive nerve inputs containing 5-hydroxytryptamine (5-HT) originating from the dorsal and medial raphe nuclei (Köhler et al., 1982; Gall and Moore, 1984; Crunelli and Segal, 1985). Autoradiographic studies demonstrated 5-HT receptors, including $5-\mathrm{HT}_{1-4}$ and $5-\mathrm{HT}_{7}$ subtypes, with high-moderate levels in the lateral septum (Biegon et al., 1982; Marcinkiewicz et al., 1984; Pazos and Palacios, 1985; Pazos et al., 1985; Vergé et al., 1986; Waeber et al., 1994; Gustafson et al., 1996; Morales et al., 1998). Electrophysiological studies showed that ionophoretic application of 5-HT increases the excitatory component of the field potential evoked in DLSN by electrical stimulation of the axons of hippocampal CA1 and CA3 neurons (DeFrance et al., 1973). Intracellular studies showed that activation of $5-\mathrm{HT}_{1 \mathrm{~A}}$ receptors produced a hyperpolarizing response (Joëls et al., 1987; Joëls and

\footnotetext{
Received Oct. 14, 2001; revised May 24, 2002; accepted May 5, 2002.

This work was supported in part by The Ishibashi Research Fund and a grant-inaid for Scientific Research (B) from the Ministry of Education, Science, Sports, and Culture of Japan. We thank Dr. C. Polosa for reading this manuscript and for helpful comments.

Correspondence should be addressed to Dr. Hiroshi Hasuo, Department of Physiology, Kurume University School of Medicine, 67 Asahi-machi, Kurume 8300011, Japan. E-mail: hhasuo@med.kurume-u.ac.jp.

Copyright (ㄷ) 2002 Society for Neuroscience $\quad 0270-6474 / 02 / 227509-09 \$ 15.00 / 0$
}

by 5 -HT. 5 -HT $(10 \mu \mathrm{M})$ and $\alpha$-methyl-5-HT $(10 \mu \mathrm{M})$ increased the frequency of miniature EPSPs (mEPSPs) without changing the mEPSP amplitude. The ratio of the paired pulse facilitation was significantly decreased by $5-\mathrm{HT}$ and $\alpha$-methyl-5-HT. The 5-HTinduced facilitation of the EPSP was blocked by calphostin C (100 $\mathrm{nM})$, a specific protein kinase $\mathrm{C}$ (PKC) inhibitor, but not by $\mathrm{N}-[2-$ ( $p$-bromocinnamylamino)ethyl]-5-isoquinolinesulfonamide (10 $\mu \mathrm{M})$, a protein kinase A inhibitor. Phorbol 12,13-dibutyrate (3 $\mu \mathrm{M})$ mimicked the facilitatory effects of $5-\mathrm{HT}$. These results suggest that 5-HT enhances the EPSP by increasing the release of glutamate via presynaptic $5-\mathrm{HT}_{2 \mathrm{~A}}$ receptors that link with $\mathrm{PKC}$ in rat DLSN neurons.

Key words: rat; dorsolateral septal nucleus; EPSP; mEPSP; paired pulse facilitation; 5- $\mathrm{HT}_{2 \mathrm{~A}}$ receptor; synaptic facilitation; PKC; G-protein
Gallagher, 1988; Akasu et al., 2000) by activating inward and outward rectifier $\mathrm{K}^{+}$currents (Yamada et al., 2001) in DLSN neurons. In addition, 5-HT strongly depressed the fast and slow IPSPs via $5-\mathrm{HT}_{1 \mathrm{~A}}$ receptors in the DLSN (Joëls and Gallagher, 1988; Gallagher et al., 1995; Akasu et al., 2000). In other brain regions, several studies have shown that 5-HT depresses excitatory synaptic transmission (Segal, 1980; Bobker and Williams, 1989; Mooney et al., 1994; Schmitz et al., 1995; Singer et al., 1996; Li and Bayliss, 1998; Hwang and Dun, 1999) or enhances neuronal excitability (Beck, 1992; Aghajanian and Marek, 1997). However, little is known about the facilitation of excitatory synaptic transmission by 5-HT except for spinal cord neurons (Hori et al., 1996). In the present study, we examined the direct effect of 5-HT on the EPSP (and EPSC) in the DLSN while inhibitory circuits were pharmacologically eliminated. The results suggest that 5-HT presynaptically enhances the EPSP (and EPSC) via $5-\mathrm{HT}_{2 \mathrm{~A}}$ receptors and that the 5-HT-induced facilitation of the EPSP is mediated by activation of protein kinase $\mathrm{C}$ (PKC). A pertussis toxin (PTX)-insensitive G-protein, linked to presynaptic $5-\mathrm{HT}_{2 \mathrm{~A}}$ receptors, may be involved.

\section{MATERIALS AND METHODS}

Transverse brain slices containing the septal nuclei were obtained in a manner described previously (Stevens et al., 1984). Briefly, male Wistar rats $(120-200 \mathrm{gm})$ were killed by decapitation. Their brains were rapidly removed and immersed for $8-10 \mathrm{sec}$ in cooled artificial CSF (ACSF; $4-6^{\circ} \mathrm{C}$ ) that was prebubbled with $95 \% \mathrm{O}_{2}$ and $5 \% \mathrm{CO}_{2}$. Brain slices $(400$ $\mu \mathrm{m}$ in thickness) were cut with a Vibroslice (Campden Instruments) and left to recover for $1 \mathrm{hr}$ in oxygenated ACSF. The slice was then transferred to a recording chamber and submerged in ACSF at $32-33^{\circ} \mathrm{C}$. The composition of the ACSF was as follows (in mM): $117 \mathrm{NaCl}, 4.7 \mathrm{KCl}, 2.5$ 
$\mathrm{CaCl}_{2}, 1.2 \mathrm{MgCl}_{2}, 25 \mathrm{NaHCO}_{3}, 1.2 \mathrm{NaHPO}_{4}$, and 11 D-glucose, $\mathrm{pH} 7.4$ and 295-305 mOsm. Intracellular recordings of the membrane potential of DLSN neurons were made by using single glass microelectrodes filled with 3 M K-acetate (tip resistance, 80-140 M 2 ). EPSPs were evoked at $0.1 \mathrm{~Hz}$ by using a concentric bipolar electrode placed on the fimbrial pathway. The perfusate routinely contained bicuculline $(15 \mu \mathrm{M})$ and (2S)-3-[[(1S)-1-(3,4-dichlorophenyl)ethyl]amino-2-hydroxypropyl](phenylmethyl) phosphinic acid (CGP 55845; $4 \mu \mathrm{M}$ ) to block inhibitory postsynaptic responses unless otherwise stated (Gallagher et al., 1995; Yamada et al., 2001). The intensity of the nerve stimulation was chosen to yield an EPSP that was one-half the size necessary to activate an action potential $(6-20 \mathrm{~V}$ for $200 \mu \mathrm{sec})$. Membrane potentials and currents were recorded with an Axoclamp-2A amplifier (Axon Instruments). Voltage-clamp recordings of the EPSC were made with discontinuous single-electrode voltage-clamp mode at a sampling rate of $2-5 \mathrm{kHz}$ and gain of $0.8 \mathrm{nA} / \mathrm{mV}$. The head stage output was continuously monitored. The efficacy of voltage clamp with a single microelectrode ranged from 90 to $95 \%$ as estimated from the difference between the clamped and unclamped EPSPs. The pClamp software program (Axon Instruments) operating on a computer (Gateway) was used for later analysis of the data. Unless otherwise stated, sample traces of synaptic potential and currents represent averages of six consecutive events. The miniature EPSP (mEPSP) was analyzed with minianalysis software (Synaptosoft). Events were accepted for analysis when they had amplitude of $>0.2 \mathrm{mV}$, had a monophasic rising phase, and decayed to baseline in an approximately exponential manner in $20 \mathrm{msec}$. In some experiments, glutamate was applied to DLSN neurons by pressure pulses (140 kPa for $30 \mathrm{msec})$ by using a Picospritzer (General Valve Co., Fairfield, NJ) from a glass pipette containing L-glutamate $(100 \mathrm{~mm})$. Experimental values are presented as the mean \pm SE. Statistical analyses were performed using Student's $t$ test. $p<0.05$ was accepted as statistically significant.

Drugs were purchased from the following sources. 5-HT creatinine sulfate complex was from Wako Pure Chemical Industries (Osaka, Japan). (-)-Bicuculline methiodide, DNQX, AP-5, $N$-ethylmaleimide (NEM), $N$ desmethylclozapine, forskolin, ( \pm )-8-hydroxy-2-(di- $N$-propylamino)tetralin hydrobromide [( \pm )-8-OH-DPAT], $N$-[2-[4-(2-methoxyphenyl)-1-piperazinyl]ethyl]- $N$-2-pyridinylcyclohexanecarboxamide (WAY 100635), phorbol 12,13-dibutyrate (PDBu), $N^{6}, 2^{\prime}-O$-dibutyryl-cAMP (db-cAMP), and calphostin $\mathrm{C}$ were purchased from Sigma (St. Louis, MO). Tetrodotoxin (TTX) was from Alomone Labs Ltd. (Jerusalem, Israel). CGP 55845, 1,4-dihydro-3-(1,2,3,6-tetrahydro-4-pyridinyl)-5H-pyrrolo[3,2-b]pyridin-5one (CP 93129), 4-amino-(6-chloro-2-pyridyl)-1-piperidine hydrochloride (SR 57227A), $\alpha$-methyl-5-(2-thienylmethoxy)-1H-indole-3-ethanamine (BW 723C86), 6-chloro-2-(1-piperazinyl)pyrazine (MK 212), $\alpha$-methyl-5HT, ( $S$ )- $N$-tert-butyl-3-(4-(2-methoxyphenyl)-piperazin-1-yl)-2-phenylpropanamide (WAY 100135), 1-(4-amino-5-chloro-2-methoxyphenyl)-3-[1-2methylsulphonylamino]ethyl-4-piperidinyl]-1-propanone (RS 67506), 5-carboxamidotryptamine maleate (5-CT), and 3-[2-[4-(4-fluorobenzoyl)1-piperidinyl]ethyl]-2,4[1H,3H]-quinazolinedione (ketanserin) were from Tocris Cookson Ltd. $N$-[2-( $p$-Bromocinnamylamino)ethyl]-5-isoquinolinesulfonamide (H-89) was purchased from Seikagagu Corp. PDBu, CGP 55845, and BW 723C86 were dissolved in dimethylsulfoxide (DMSO) and added to the ACSF, in which the final concentration of DMSO $(0.1 \%)$ had no direct effect on DLSN neurons. Other drugs were dissolved in the ACSF.

\section{RESULTS}

\section{Effects of 5-HT on the evoked EPSP and EPSC in DLSN neurons}

The resting membrane potential and input resistance of DLSN neurons were $-60 \pm 0.5 \mathrm{mV}(n=73)$ and $119 \pm 3 \mathrm{M} \Omega(n=73)$, respectively. Approximately $50 \%$ of the neurons showed spontaneous firing at the resting membrane potential. Figure $1 A$ shows the effects of 5-HT on spontaneous action potentials and EPSPs in a DLSN neuron. Application of 5-HT to the bath produced a hyperpolarizing response that completely blocked the spontaneous firing (Fig. 1A1). However, the EPSP-mediated action potential evoked by stimulation ( $10 \mathrm{~V}$ for $200 \mu \mathrm{sec}$ ) of the fimbrial pathway was not blocked during the 5-HT-induced hyperpolarization (Fig. 1A2). We examined the direct effect of 5-HT (10 $\mu \mathrm{M})$ on the EPSP in DLSN neurons, in which the membrane potential was initially held at $-68-70 \mathrm{mV}$ by injecting DC current
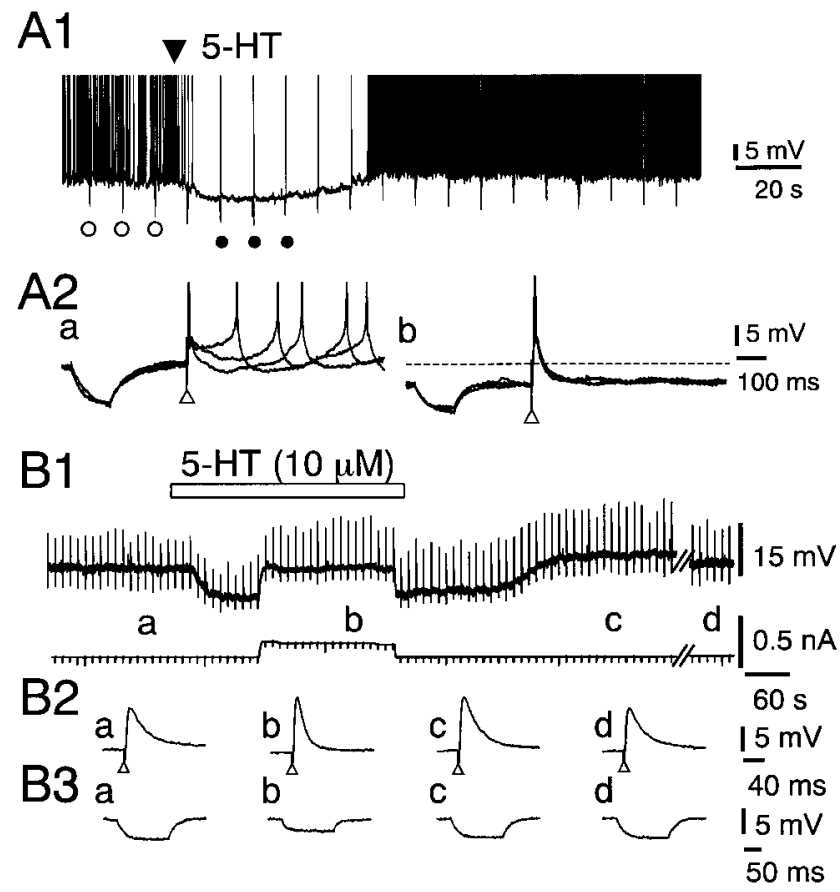

Figure 1. Effects of 5-HT $(10 \mu \mathrm{M})$ on excitatory synaptic transmission and membrane properties of DLSN neurons. The ACSF contained bicuculline $(15 \mu \mathrm{M})$ and CGP $55845(4 \mu \mathrm{M})$ to block IPSPs. $A 1$, Continuous chart recording of the membrane potential of a DLSN neuron. The resting membrane potential was $-58 \mathrm{mV}$. 5 -HT was applied topically at the time indicated by the filled triangle. A2, Records $a$ and $b$ depict three traces obtained before and after application of 5-HT at the time indicated by open and filled circles in A1, respectively. Open triangles indicate time of fimbrial nerve stimulation. Note that action potentials were elicited by enhanced EPSPs. Electrotonic potentials were produced by applying rectangular current pulses $(50 \mathrm{pA}$ for $120 \mathrm{msec})$. The dotted line indicates the original membrane potential level. $B 1$, Continuous chart recordings of the membrane potential (top trace) and current (bottom trace). The initial holding membrane potential was $-70 \mathrm{mV}$. In the top trace, upward and downward deflections represent EPSPs and electrotonic potentials, respectively. The period of bath application of 5-HT $(10 \mu \mathrm{M})$ is indicated by the horizontal bar. B2, Averaged six EPSPs taken at the time indicated by the respective letters in $B 1$. In record $c$, the membrane potential was returned to $-70 \mathrm{mV}$ by injecting outward $\mathrm{DC}$ current into the neuron. Record $f$ was taken 15 min after washout of 5-HT. B3, Averaged six electrotonic potentials taken at the time indicated by the respective letters in $B 1$. The electrotonic potentials were produced by rectangular current pulses (50 pA for $150 \mathrm{msec})$.

into the neurons. The hyperpolarizing response induced by $5-\mathrm{HT}$ $(10 \mu \mathrm{M})$ was associated with a decrease in the input membrane resistance (Fig. 1B). Pooled data showed that 5-HT $(10 \mu \mathrm{M})$ produced a $29 \pm 5.9 \%(n=16)$ decrease in the input membrane resistance. The facilitation of the EPSP amplitude was clearly seen when the 5-HT-induced hyperpolarization was nullified by injecting depolarizing DC current (Fig. 1B2,b). Pooled data showed that 5 -HT $(10 \mu \mathrm{M})$ produced a $36 \pm 4 \%(n=16)$ increase in the amplitude of the EPSP. The EPSP recovered 10-40 min after removal of 5-HT from the external solution, and the mean recovery time was 18 min (Fig. $1 B 2, d$ ). The membrane potential and input resistance of DLSN neurons recovered within 6 min after reapplication of the ACSF (Fig. 1B3,c). In some neurons that showed no obvious facilitation of the EPSP, the effect of 5-HT was use-dependent. Figure $2 A$ shows an example of these experiments. A brief application of 5-HT (10 $\mu \mathrm{M}$ for $6 \mathrm{~min}) \mathrm{did}$ not produce visible facilitation of the EPSP. Subsequent exposure of DLSN neurons to 5-HT, however, produced a clear facilitation 


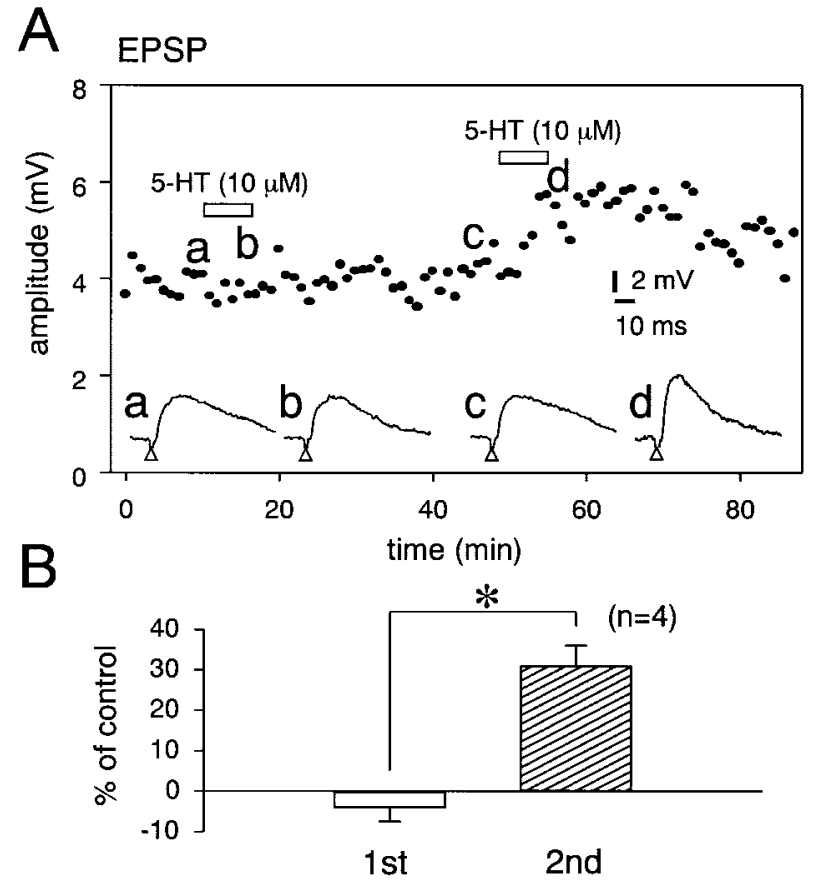

Figure 2. Effects of repeated application of 5-HT on the EPSP. A, Time course of the effects of repeated application of 5-HT on the amplitude of EPSPs. 5-HT $(10 \mu \mathrm{M})$ was applied to the bath for $6 \mathrm{~min}$ at the times indicated by the open squares. Bottom traces are sample records of the facilitation of the EPSP induced by repeated application of 5-HT $(10 \mu \mathrm{M})$. Records $a-d$ are recorded at the times indicated by the respective letters on the graph. The holding membrane potential was $-68 \mathrm{mV}$. B, Pooled data for the effects of 5-HT on the EPSP. Open and hatched columns show first and second applications of 5-HT $(10 \mu \mathrm{M})$. Abscissa, Percentage facilitation of the EPSP amplitude. The number of experiments is shown in parentheses. Error bars indicate SEM. *Statistical significant $(p<0.01)$.

of the EPSP (Fig. 2A). Furthermore, the enhanced EPSP lasted for $>40 \mathrm{~min}$ even after removal of 5-HT from external solution. Statistical data showed that the second application of 5-HT for 6 min produced $31 \pm 2 \%(n=4)$ facilitation of the EPSP (Fig. $2 B$ ).

Figure $3 A$ shows the effect of 5-HT $(10 \mu \mathrm{M})$ on the EPSC examined by using the single-microelectrode voltage-clamp technique. Application of 5-HT $(10 \mu \mathrm{M})$ produced an outward current with amplitude of $158 \pm 12 \mathrm{pA}(n=17)$ at a membrane potential of $-70 \mathrm{mV}$ (Fig. 3A,b). 5-HT $(10 \mu \mathrm{M})$ increased the amplitude of the EPSP; averaged amplitudes of 30 EPSCs obtained before and 5 min after application of 5-HT $(10 \mu \mathrm{M})$ were $125 \pm 4$ and $176 \pm$ 8 pA, respectively, in this neuron (Fig. $3 A$ ). Pooled data showed that 5 -HT $(10 \mu \mathrm{M})$ produced a $39 \pm 3 \%(n=11)$ increase in the amplitude of the EPSC. The facilitation of the EPSC amplitude by 5 -HT was concentration-dependent. At a concentration of $1 \mu \mathrm{M}$, 5-HT produced a visible $(12 \pm 4 \% ; n=10)$ facilitation of the EPSC. At a concentration of $10 \mu \mathrm{M}$, the facilitation of the EPSC reached its maximum within 5-6 min after beginning of the application of 5-HT. Increased EPSCs returned to the control level within 10-30 min after withdrawal of 5-HT from the ACSF. The effect of $\alpha$-methyl-5-HT, a $5-\mathrm{HT}_{2}$ receptor agonist, on the EPSC was examined in voltage-clamped neurons (Fig. 3B). Bath application of $\alpha$-methyl-5-HT $(10 \mu \mathrm{M})$ produced an outward current (118 $\pm 10 \mathrm{pA} ; n=7)$. The averaged amplitudes of 30 EPSCs were $207 \pm 8$ and $309 \pm 10 \mathrm{pA}$ in the absence and presence of $\alpha$-methyl-5-HT $(10 \mu \mathrm{M})$, respectively. Pooled data showed that $\alpha$-methyl-5-HT $(10 \mu \mathrm{M})$ produced a $49 \pm 7 \%(n=7)$

\section{A EPSC}

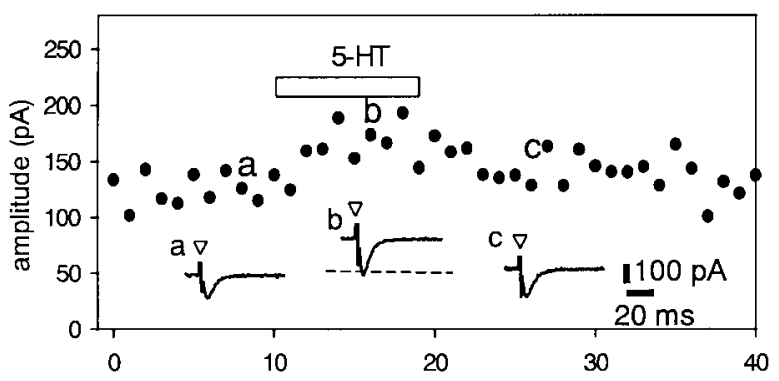

B EPSC

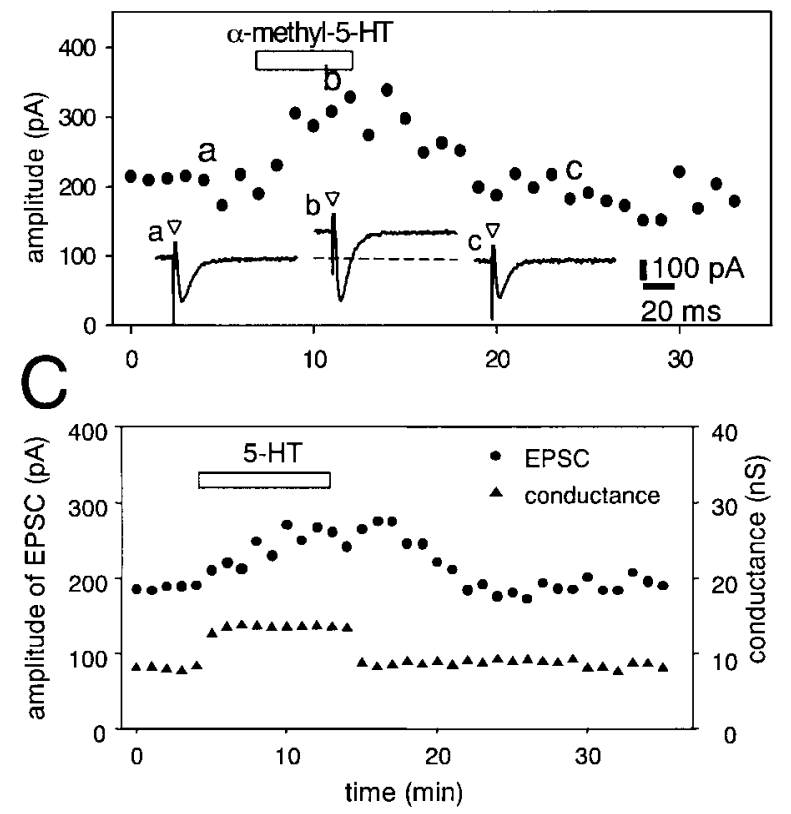

Figure 3. Effects of 5-HT (10 $\mu \mathrm{M})$ and $\alpha$-methyl-5-HT (10 $\mu \mathrm{M})$ on EPSCs in DLSN neurons. ACSF contained bicuculline $(15 \mu \mathrm{M})$ and CGP 55845 $(4 \mu \mathrm{M})$ to block IPSPs in all experiments. Data points are averages of six responses. Periods of drug application are indicated by horizontal bars. Bottom traces in $A$ and $B$ are sample records of neuron responses at the times indicated by the corresponding letters on the graph. Open triangles indicate the time of fimbria stimulation. $A$, Facilitation of the EPSC induced by 5 -HT $(10 \mu \mathrm{M})$ in a DLSN neuron voltage-clamped at $-70 \mathrm{mV}$. The dotted line indicates predrug membrane current (also in $B$ ). $B$, Effects of $\alpha$-methyl-5-HT $(10 \mu \mathrm{M})$ on the EPSC. Holding membrane potential was $-70 \mathrm{mV}$. C. Time course of the effects of 5-HT $(3 \mu \mathrm{M})$ on the EPSC and the membrane conductance. The membrane conductance was monitored via the change in inward currents induced by hyperpolarizing voltage commands ( $10 \mathrm{mV}$ for $80 \mathrm{msec})$. The facilitation of the EPSC by 5-HT was preceded by the membrane conductance change.

increase in the amplitude of the EPSC. The changes in the membrane conductance reached a maximum within 2 min after beginning of the application of 5-HT $(10 \mu \mathrm{M})$. The conductance returned to the control value within 5 min after washout of 5-HT (Fig. 2C).

Effects of BW 723C86, a selective 5- $\mathrm{HT}_{2 \mathrm{~B}}$ receptor agonist, and MK 212, a selective 5- $\mathrm{HT}_{2 \mathrm{C}}$ receptor agonist, on the EPSP were examined. The amplitude of the EPSP was not significantly increased by BW 723C86 (10 $\mu \mathrm{M} ; 4 \pm 2 \% ; n=4)$ or MK $212(10$ $\mu \mathrm{M} ;-2 \pm 2 \% ; n=4)$. Figure $4 A$ shows the effects of ketanserin $(10 \mu \mathrm{M})$, a $5-\mathrm{HT}_{2 \mathrm{~A} / 2 \mathrm{C}}$ receptor antagonist, on the facilitation of the EPSP induced by $\alpha$-methyl-5-HT $(10 \mu \mathrm{M})$ in a DLSN neuron. In the absence of ketanserin, the averaged amplitude of 30 EPSPs 


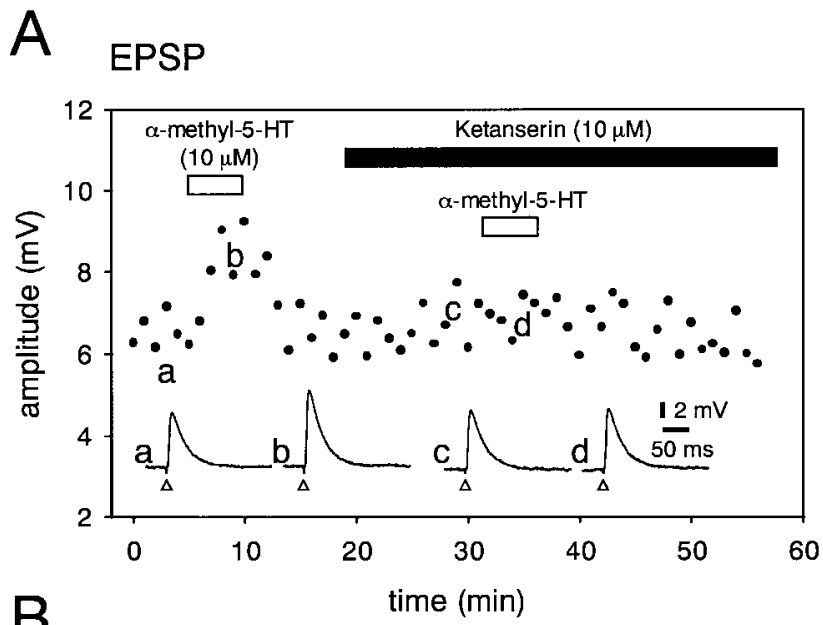

$\mathrm{B}$

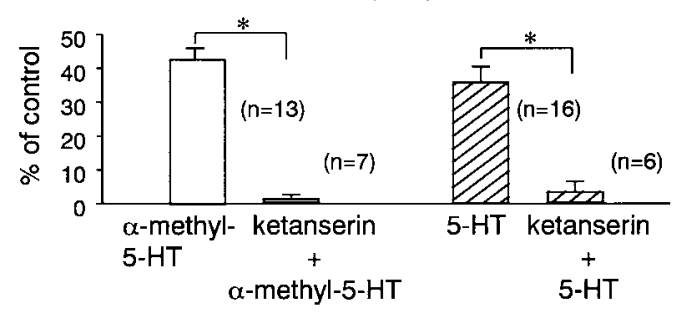

Figure 4. Effect of ketanserin $(10 \mu \mathrm{M})$ on the facilitation of the EPSP induced by $\alpha$-methyl-5-HT (10 $\mu \mathrm{M})$. $A$, Effects of $\alpha$-methyl-5-HT (10 $\mu \mathrm{M})$ on the EPSP examined in the absence and presence of ketanserin $(10 \mu \mathrm{M})$ in a DLSN neuron. Data points are averages of six responses. The period of drug application is indicated by horizontal bars. Bottom traces are sample records of neuron responses at the time indicated by the corresponding letters on the graph. Open triangles indicate the time of fimbria stimulation. $B$, Pooled data for the facilitation of the EPSP induced by $\alpha$-methyl-5-HT (10 $\mu \mathrm{M}$; open columns) and 5-HT (10 $\mu \mathrm{M}$; hatched columns) in the absence and presence of ketanserin $(10 \mu \mathrm{M})$. The number of experiments is shown in parentheses. Error bars indicate SEM. Ordinate, Percentage facilitation of the EPSP amplitude. *Statistical significance $(p<0.01)$.

was increased from $6.4 \pm 0.2$ to $8.9 \pm 0.4 \mathrm{mV}$ by $\alpha$-methyl-5-HT. In the presence of $10 \mu \mathrm{M}$ ketanserin, the average amplitude of 30 EPSPs was $6.5 \pm 0.4 \mathrm{mV}$ for control and $7.0 \pm 0.3 \mathrm{mV}$ for $\alpha$-methyl-5-HT (10 $\mu \mathrm{M})$ (Fig. 4A). The pooled data showed that $\alpha$-methyl-5-HT $(10 \mu \mathrm{M})$ produced only a $1.4 \pm 1.1 \%(n=7)$ increase in the amplitude of the EPSPs in neurons treated with ketanserin $(10 \mu \mathrm{M})$ (Fig. $4 B)$. 5-HT $(10 \mu \mathrm{M})$ also produced only a $3.7 \pm 2.8 \%(n=6)$ increase in the EPSP amplitude in the presence of ketanserin $(10 \mu \mathrm{M})$ (Fig. $4 B)$. The effect of $N$-desmethylclozapine, a selective antagonist for $5-\mathrm{HT}_{2 \mathrm{C}}$ receptors, on the 5-HT-induced facilitation of the EPSP was also examined in DLSN neurons. In the presence of $N$-desmethylclozapine $(10 \mu \mathrm{M})$, $\alpha$-methyl-5-HT $(10 \mu \mathrm{M})$ produced a $39 \pm 6 \%(n=5)$ increase in the amplitudes of EPSPs (data not shown). These results suggest that $5-\mathrm{HT}_{2 \mathrm{~A}}$ receptors are responsible for the 5-HT-induced facilitation of the EPSP in DLSN neurons. The effect of 8-OH-DPAT, an agonist for $5-\mathrm{HT}_{1 \mathrm{~A}}$ and $5-\mathrm{HT}_{7}$ receptors, on the EPSP was examined, because the activation of $5-\mathrm{HT}_{1 \mathrm{~A}}$ receptors mediates a hyperpolarizing response in DLSN neurons (Joëls and Gallagher, 1988; Akasu et al., 2000). When the ( \pm )-8-OH-DPAT-induced hyperpolarization was nullified by injection of depolarizing DC current, 8-OH-DPAT $(10 \mu \mathrm{M})$ produced $21 \pm 6 \%$ depression of the EPSP in 5 of 12 cells. However, in the remaining 7 neurons, 8-OH-DPAT $(10 \mu \mathrm{M})$ did not change $(-6 \pm 3 \%)$ the amplitude of the EPSP. WAY $100135(10 \mu \mathrm{M})$, a selective $5-\mathrm{HT}_{1 \mathrm{~A}}$ receptor antagonist, blocked the 8-OH-DPAT-induced depression of the EPSP $(n=3)$. We examined the effects of 5-HT on the membrane potential of DLSN neurons and the EPSP in the presence of WAY 100635, another selective $5-\mathrm{HT}_{1 \mathrm{~A}}$ receptor antagonist. 5-HT $(10 \mu \mathrm{M})$ did not produce a hyperpolarizing response but produced a $52 \pm 5 \%(n=6)$ increase in the amplitude of the EPSP in the presence of WAY $100635(10 \mu \mathrm{M})$. CP 93129 (10 $\mu \mathrm{M})$, a $5-\mathrm{HT}_{1 \mathrm{~B}}$ receptor agonist, SR 57227A $(20 \mu \mathrm{M})$, a $5-\mathrm{HT}_{3}$ agonist, RS $67506(10 \mu \mathrm{M})$, a 5-HT 4 receptor agonist, and 5-CT (2 $\mu \mathrm{M}$ ), a $5-\mathrm{HT}_{1,5}$ and $5-\mathrm{HT}_{7}$ receptor agonist, produced no significant change in the amplitude of the EPSP in DLSN neurons $(n=$ 4 for each experiment).

We examined whether the facilitation of the EPSP by $5-\mathrm{HT}$ is attributable to increased sensitivity of receptors at the postsynaptic membrane. DLSN neurons were superfused with ACSF containing TTX $(1 \mu \mathrm{M})$. Under the voltage-clamp condition, L-glutamate was applied to the recorded neurons by pressure pulses from a broken tip glass pipette containing L-glutamate. Pressure application of glutamate to DLSN neurons produced an inward current associated with an increase in the membrane conductance. Pooled data showed that the amplitudes of the exogenous glutamate-induced current were $346 \pm 40 \mathrm{pA}(n=5)$ and $338 \pm 37 \mathrm{pA}(n=5)$ in the absence and presence of 5-HT (10 $\mu \mathrm{M})$, respectively. The difference between these data is not statistically significant. These results suggest that the 5-HT-induced enhancement of the EPSP is not attributable to the increase in the glutamate response at the postsynaptic membrane.

\section{Effect of 5-HT on the mEPSCs}

The evidence that an agonist can increase the frequency of mEPSPs without changing their amplitudes suggests presynaptic facilitation of excitatory synaptic transmission (Katz, 1969; Thompson et al., 1993). Figure 5 shows the effects of $\alpha$-methyl5-HT on the frequency and amplitude of mEPSPs in DLSN neurons. In this experiment, WAY 100135 (5 $\mu \mathrm{M})$ and TTX (1 $\mu \mathrm{M})$ were routinely applied to the external solution to block the 5-HT-induced hyperpolarization and action potential, respectively. The amplitude and frequency of mEPSPs were not significantly affected by these two blockers. Figure $5 A$ shows amplitude histograms of the mEPSPs taken before and $10 \mathrm{~min}$ after application of $\alpha$-methyl-5-HT $(10 \mu \mathrm{M})$. $\alpha$-Methyl-5-HT $(10 \mu \mathrm{M})$ increased the number of mEPSPs. The cumulative amplitude distribution of mEPSPs was plotted in the absence or presence of $\alpha$-methyl-5-HT (10 $\left.\mu \mathrm{M}^{6}\right)$ (Fig. 5B). $\alpha$-Methyl-5-HT (10 $\left.\mu \mathrm{M}\right) \mathrm{did}$ not change the mean amplitude of the mEPSPs: $0.58 \pm 0.07 \mathrm{mV}$ $(n=5)$ for control and $0.56 \pm 0.06(n=5) \mathrm{mV}$ for $\alpha$-methyl-5-HT $(10 \mu \mathrm{M}) . \alpha$-Methyl-5-HT had no effect on the time course of the mEPSP, as shown by the traces of digitally averaged mEPSPs (Fig. $5 B$, traces $a, b$ ). The cumulative probability distribution of interevent intervals was plotted in the absence and presence of $\alpha$-methyl-5-HT (10 $\mu \mathrm{M}$ ) (Fig. 5C). $\alpha$-Methyl-5-HT (10 $\mu \mathrm{M})$ caused a shift in the interevent interval distribution toward shorter intervals, indicating higher frequencies. The mean frequency of mEPSPs was increased from 0.38 to $0.62 \mathrm{~Hz}$ in the presence of $\alpha$-methyl-5-HT (10 $\mu \mathrm{M})$. Pooled data showed that $\alpha$-methyl-5-HT $(10 \mu \mathrm{M})$ produced a $72 \pm 15 \%(n=5)$ increase in the frequency of the mEPSP. The effect of 5-HT on the mEPSP was also examined in DLSN neurons. 5-HT significantly increased the number of mEPSPs. The mean peak amplitude was not affected (control, $0.62 \pm 0.05 \mathrm{mV} ; 5-\mathrm{HT}, 0.56 \pm 0.08 \mathrm{mV}$ ) in five neurons. In these five neurons treated with $5-\mathrm{HT}$, the frequency of 


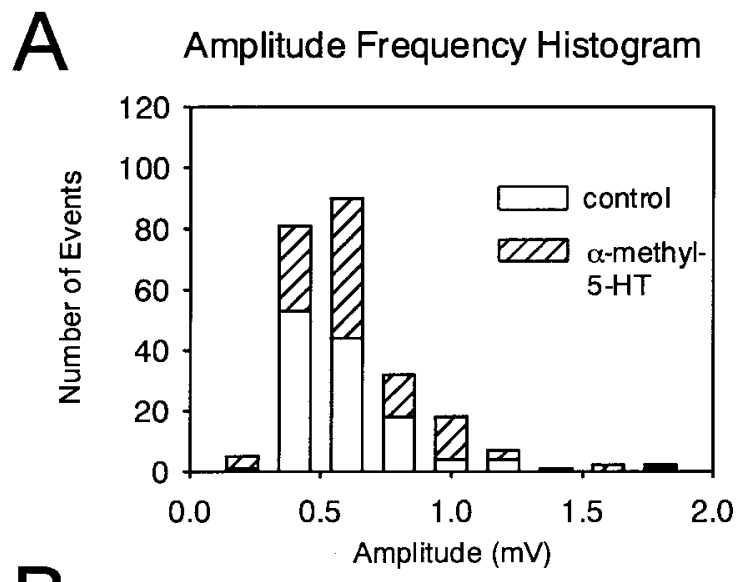

B

\section{Cumulative Amplitude Histogram}

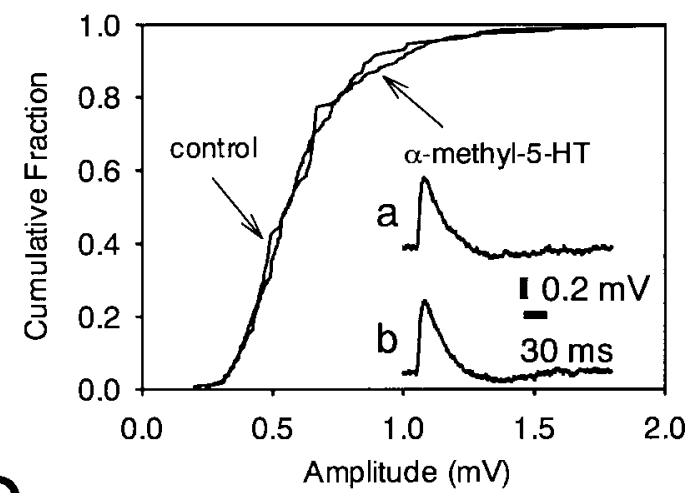

C
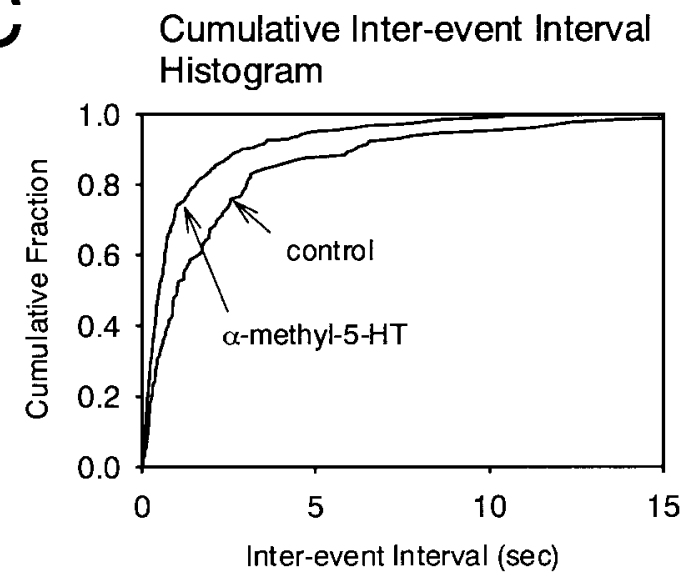

Figure 5. Effect of $\alpha$-methyl-5-HT on the mEPSP. mEPSPs were recorded in the presence of TTX $(1 \mu \mathrm{M})$ and WAY $100135(5 \mu \mathrm{M})$. The resting membrane potential was $-68 \mathrm{mV}$. $A$, Amplitude histogram of mEPSPs recorded before (open columns) and during (hatched columns) application of $\alpha$-methyl-5-HT. $B$, Cumulative probability distribution of peak amplitudes of mEPSP before and during application of $\alpha$-methyl-5-HT (10 $\mu \mathrm{M})$ in the same neuron as in $A$. Traces $a$ and $b$ show the averaged mEPSP (65 events each) obtained before and during application of $\alpha$-methyl-5-HT (10 $\mu \mathrm{M})$, respectively. $C$, Cumulative probability distribution of interevent intervals of mEPSPs before and during application of $\alpha$-methyl-5-HT (10 $\mu \mathrm{M})$ in the same neuron as in $A$. The interevent interval was decreased, but the amplitude distribution was unaffected by $\alpha$-methyl-5-HT.

mEPSPs increased from $0.27 \pm 0.04$ to $0.51 \pm 0.1 \mathrm{~Hz}(p<0.05)$. The 5-HT-induced increase in the frequency of mEPSP was $90 \pm$ $19 \%(n=5)$. These results suggest that 5-HT enhances the spontaneous release of glutamate.

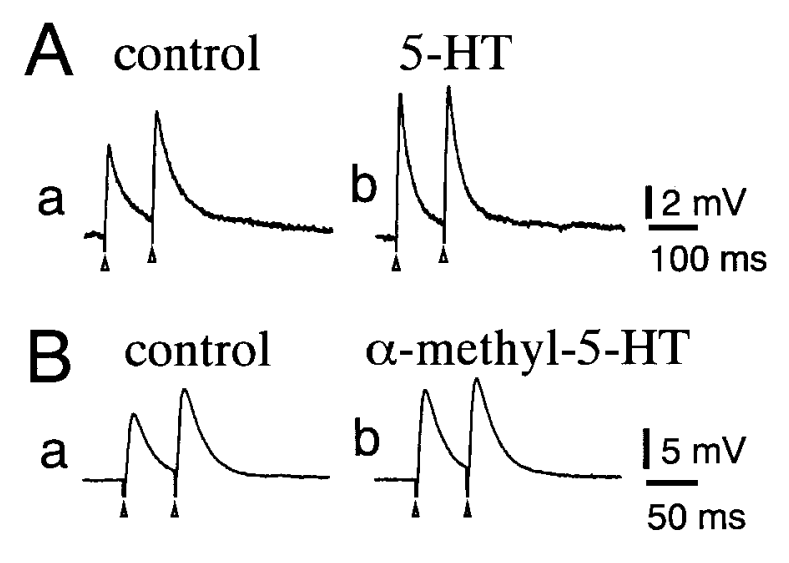

C Paired-pulse facilitation

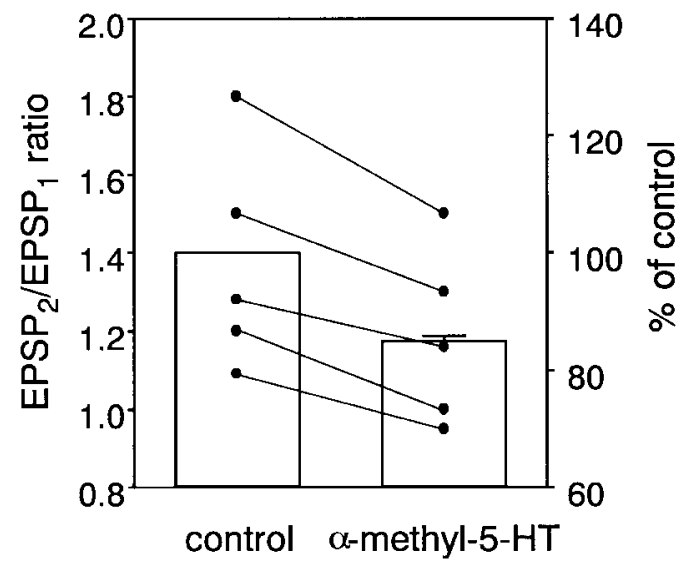

Figure 6. Effects on paired pulse facilitation of the EPSP. $A$, Effects of 5 -HT on the EPSP produced by paired pulse stimulation $(100 \mathrm{msec}$ interpulse interval) in a DLSN neuron. The ACSF contained bicuculline $(15 \mu \mathrm{M})$ and CGP $55845(4 \mu \mathrm{M})$. Two consecutive EPSPs were evoked in the absence $(a)$ and presence $(b)$ of 5-HT $(10 \mu \mathrm{M})$. B, Effect of $\alpha$-methyl5 -HT $(10 \mu \mathrm{M})$ on EPSPs evoked by paired pulse stimulation with an interpulse interval of $50 \mathrm{msec}$ in a DLSN neuron. Records $a$ and $b$ were taken before and 5 min after application of $\alpha$-methyl-5-HT (10 $\mu \mathrm{M})$. In $A$ and $B$, sample traces represent the digital average of six events. $C$, Pooled data from five neurons for the effects of $\alpha$-methyl-5-HT $(10 \mu \mathrm{M})$ on the paired pulse facilitation of the EPSP. Data points represent the paired pulse ratios obtained in the absence (left) and presence (right) of $\alpha$-methyl-5-HT $(10 \mu \mathrm{M})$. Columns show the mean \pm SEM for the depression of the paired pulse ratio in the presence of $\alpha$-methyl-5-HT (10 $\mu \mathrm{M}$; right column). The paired pulse ratio obtained before application of $\alpha$-methyl-5-HT (left column) was taken as $100 \%$.

\section{Effect of 5-HT on paired pulse facilitation of the EPSP}

When the fimbrial pathway was stimulated by two consecutive pulses, paired pulse facilitation of the EPSP was recorded in DLSN neurons treated with bicuculline $(15 \mu \mathrm{M})$ and CGP 55845 (4 $\mu \mathrm{M})$ (Hasuo and Akasu, 2001). If a neurotransmitter (or agonist) facilitates the release probability, the paired pulse ratio would decrease (Manabe et al., 1993; Debanne et al., 1996). We measured the peak amplitude of the EPSPs evoked by a pair of pulses with an interstimulus interval of 50 or $100 \mathrm{msec}$ and calculated the amplitude ratio of the second to the first EPSP in each pair. Figure 6 shows an example of these experiments. In the absence of 5-HT, the averaged amplitude ratio of the second to the first EPSP was 1.2, indicating paired pulse facilitation. When 5-HT $(10 \mu \mathrm{M})$ was applied to the external solution, both the first 

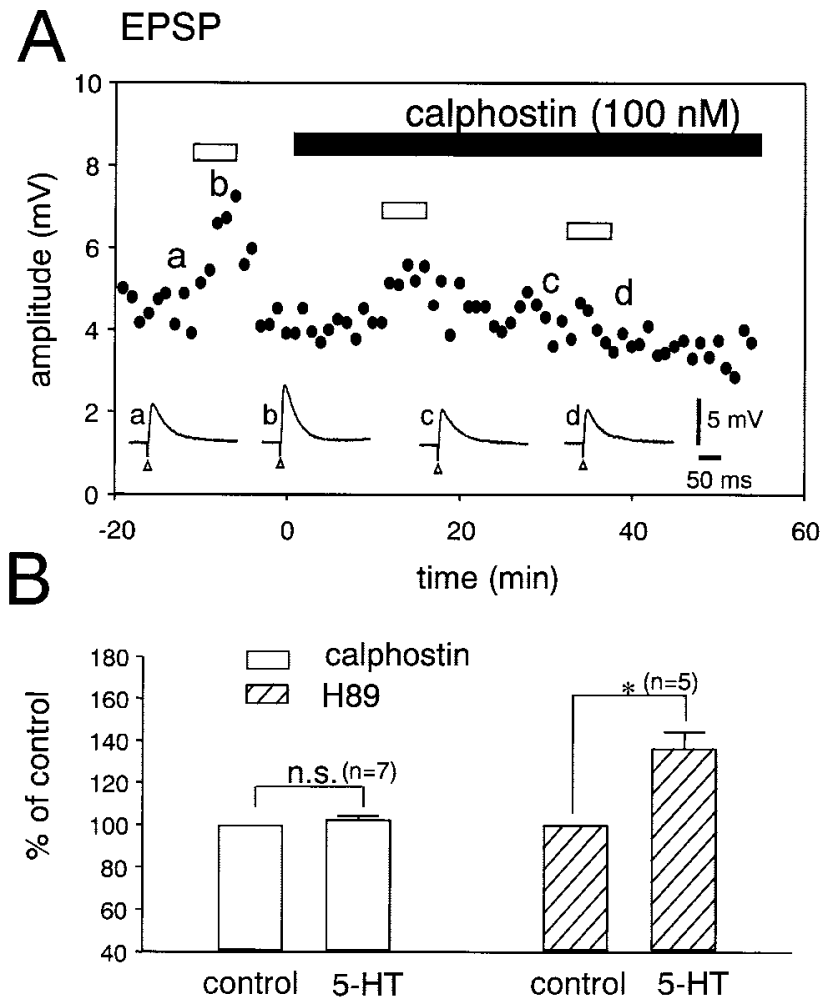

Figure 7. Effects of protein kinase inhibitors on the 5-HT-induced facilitation of the EPSP. A, Effect of 5-HT on the EPSP before and after application of calphostin C (100 nM). Data points are averages of six responses. The period of drug application is indicated by horizontal bars. Bottom traces show sample records of neuron responses at the times indicated by the corresponding letters on the graph. Open triangles indicate the time of fimbria stimulation. $B$, Pooled data for the 5-HT-induced facilitation of the EPSP. Open and hatched columns show the presence of calphostin $\mathrm{C}$ and $\mathrm{H}-89$, respectively. The amplitude of the EPSP recorded before application of 5-HT is taken as $100 \%$. The number of experiments is shown in parentheses. Error bars indicate SEM. n.s., Difference has no statistical significance.

and second EPSPs in the pair increased their amplitudes. However, the facilitation of the first EPSP was greater than that of the second, decreasing the paired pulse ratio to 1.0 in this neuron (Fig. 6A). Figure 6B shows the effect of $\alpha$-methyl-5-HT on the paired pulse facilitation in a DLSN neuron. $\alpha$-Methyl-5-HT (10 $\mu \mathrm{M}$ ) increased the amplitude of both the first and second EPSPs in the pair and decreased the pair pulse ratio from 1.2 to 1.0. Figure $6 C$ shows pooled data for the depression of the paired pulse ratio induced by $\alpha$-methyl-5-HT. In these experiments, $\alpha$-methyl-5-HT (10 $\mu \mathrm{M})$ depressed the paired pulse ratio to $85 \pm$ $1 \%(n=5)$ of control. These data suggest that 5-HT increases the probability of glutamate release from a readily releasable pool in presynaptic nerve terminals.

\section{Protein kinase C mediates the 5-HT-induced facilitation of the EPSP}

We examined the contribution of protein kinases to the 5-HTinduced facilitation of the EPSP in the DLSN. Figure $7 A$ shows the effect of 5-HT on the EPSP examined before and during the application of calphostin C, a specific inhibitor for PKC (Kobayashi et al., 1989). In this particular cell, 5-HT increased the averaged amplitude of 30 EPSPs from $4.5 \pm 0.6$ to $7.0 \pm 0.4 \mathrm{mV}$. During the application of calphostin C (100 nM), the facilitation of the EPSP induced by 5-HT decreased with time. Application of calphostin C (100 nM) for 20 min completely abolished the 5-HTinduced facilitation of the EPSP. Pooled data showed that 5-HT $(10 \mu \mathrm{M})$ produced only a $3 \pm 1 \%(n=7)$ increase in the EPSP amplitude in neurons treated with calphostin $\mathrm{C}(100 \mathrm{~nm})$ for 30 min (Fig. 7A). These data suggest that PKC plays a role in the 5-HT-induced facilitation of the EPSP in DLSN neurons. We also examined a possible contribution of protein kinase A (PKA) to the 5-HT-induced potentiation of the EPSP, because db-cAMP $(1 \mathrm{mM})$ and forskolin $(10 \mu \mathrm{M})$ produced $90 \pm 13 \%(n=6)$ and $132 \pm 25 \%(n=6)$ increases, respectively, in the amplitudes of EPSPs. However, in the presence of H-89 $(10 \mu \mathrm{M})$, a membranepermeable and selective inhibitor of PKA (Chijiwa et al., 1990), 5-HT $(10 \mu \mathrm{M})$ produced a typical facilitation $(36 \pm 8 \% ; n=5)$ of the amplitude of the EPSP (Fig. $7 B$ ). At a concentration of $10 \mu \mathrm{M}$, H-89 suppressed the facilitation of the EPSP produced by application of forskolin for $10 \mathrm{~min}(n=3$; data not shown). Therefore, a db-cAMP-dependent process may not be involved in the 5-HTinduced facilitation of the EPSP in DLSN neurons.

The effect of PDBu, an activator of PKC, on the EPSP was examined in DLSN neurons. Bath application of PDBu $(3 \mu \mathrm{M})$ produced a $127 \pm 30 \%(n=5)$ increase in the amplitude of the EPSP (Fig. $8 A$ ). Figure $8 B$ shows the effect of PDBu on the paired pulse facilitation of the EPSP recorded from a DLSN neuron treated with bicuculline $(15 \mu \mathrm{M})$ and CGP $55845(4 \mu \mathrm{M})$. Application of PDBu $(3 \mu \mathrm{M})$ to the ACSF for $10 \mathrm{~min}$ clearly increased the amplitude of both first and second EPSPs. The facilitation of the first EPSP was greater than that of the second. Thus, paired pulse facilitation was changed to paired pulse depression by $\mathrm{PDBu}$ in this particular neuron (Fig. $8 \mathrm{~B}$ ). Pooled data showed that PDBu $(3 \mu \mathrm{M})$ depressed the paired pulse ratio from $1.16 \pm 0.04 \%(n=3)$ to $0.80 \pm 0.07 \%(n=3)$. We also examined the effect of PDBu on the mEPSPs. Figure $8 C$ shows the cumulative amplitude distribution of mEPSPs obtained in the absence and presence of PDBu. The mean amplitudes of the mEPSCs were $0.52 \pm 0.03 \mathrm{mV}(n=4)$ for control and $0.49 \pm 0.04 \mathrm{mV}(n=$ 4) for PDBu $(3 \mu \mathrm{M})$. Thus, $\mathrm{PDBu}(3 \mu \mathrm{M})$ produced no significant change in the amplitude distribution $(p>0.2)$. PDBu had no effect on the time course of the mEPSP as shown by the traces of digitally averaged mEPSPs in Figure $8 C$, traces $a$ and $b$. The cumulative interevent interval probability distributions were plotted in the absence and presence of PDBu (3 $\mu \mathrm{M})$ (Fig. 8D). PDBu $(3 \mu \mathrm{M})$ caused a shift of the interevent interval distribution toward shorter intervals, indicating higher frequencies. The mean frequency of mEPSPs increased from $0.30 \pm 0.03 \mathrm{~Hz}(n=4)$ to $1.65 \pm 0.24 \mathrm{~Hz}(n=4)$ in the presence of PDBu $(3 \mu \mathrm{M})$. These results indicate that $\mathrm{PDBu}$ increases glutamate release from presynaptic nerve terminals.

Molecular cloning has established that all 5-HT receptor subtypes, except $5-\mathrm{HT}_{3}$ receptors, couple to the G-protein-coupled receptor (Hoyer et al., 1994). It has been reported that NEM, a membrane-permeable inhibitor for PTX-sensitive G-proteins (Nakajima et al., 1990; Shapiro et al., 1994), irreversibly blocks the 5-HT-induced hyperpolarization (and current) in DLSN neurons (Yamada et al., 2001). In the present study, we examined the effect of NEM on the facilitation of the EPSP induced by 5-HT in DLSN neurons (Fig. 9). In the control ACSF, 5-HT (10 $\mu \mathrm{M})$ caused a hyperpolarization in DLSN neurons and enhanced the EPSP amplitude (Fig. 9A, $a, B, a)$. Application of NEM $(200 \mu \mathrm{M})$ for $>30$ min markedly increased the spontaneous EPSPs and strongly depressed the hyperpolarization induced by 5-HT (10 $\mu \mathrm{M})$ (Fig. 9A,b). At the same time, 5-HT (10 $\mu \mathrm{M})$, however, produced a typical facilitation $(44 \pm 10 \% ; n=4)$ of the EPSP 


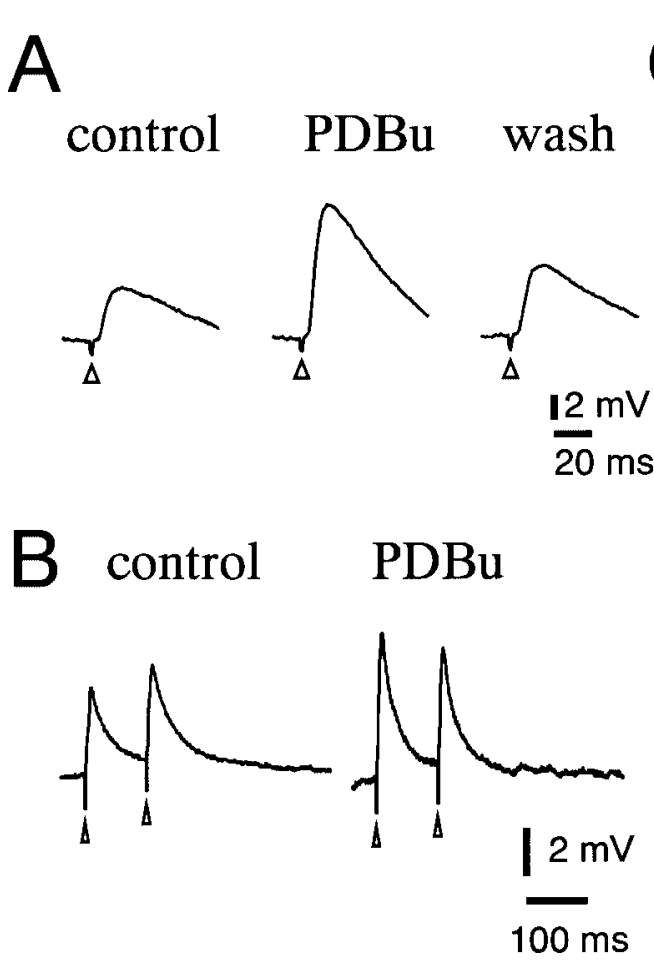

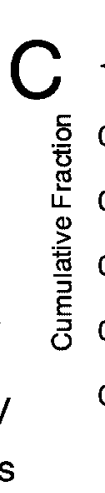

Cumulative Amplitude Histogram
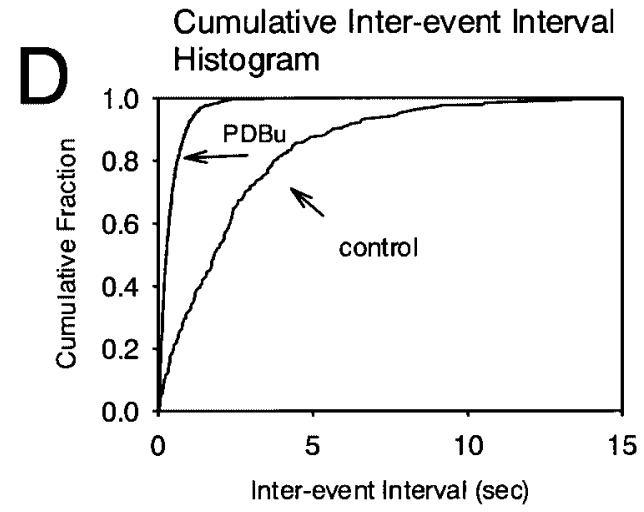

Figure 8. PDBu $(3 \mu \mathrm{M})$ increases excitatory synaptic transmission in DLSN neurons. $A$, Effect of PDBu $(3 \mu \mathrm{M})$ on the evoked EPSP in a DLSN neurons. Left and middle traces were obtained before and $15 \mathrm{~min}$ after bath application of $\mathrm{PDBu}$. The right trace was taken $100 \mathrm{~min}$ after withdrawal of PDBu. $B$, Effect of $\mathrm{PDBu}(3 \mu \mathrm{M})$ on the paired pulse facilitation of the EPSP. Left and right traces were obtained before and $10 \mathrm{~min}$ after bath application of PDBu. $C$, Cumulative amplitude distribution of mEPSPs recorded before and during application of $\mathrm{PDBu}(3 \mu \mathrm{M})$. mEPSPs were recorded in the presence of TTX $(1 \mu \mathrm{M})$ and bicuculline $(15 \mu \mathrm{M})$. Traces $a$ and $b$ show the mEPSP shape before and during application of PDBu. $D$, Cumulative probability distribution of interevent intervals of mEPSC in control and during application of PDBu in the same neuron (as $A$ ). The interevent interval was decreased, but the amplitude distribution was unaffected by PDBu.
(Fig. 9B, b). It has been reported that baclofen, a GABA $\mathrm{B}_{\mathrm{B}}$ receptor agonist, presynaptically depresses the EPSC in DLSN neurons (Yamada et al., 1999), and that the presynaptic $\mathrm{GABA}_{\mathrm{B}}$ receptors on glutamatergic nerve terminals couple to NEM-sensitive G-protein in rat auditory brainstem (Isaacson, 1998). We examined the effect of baclofen on the EPSP in neurons treated with NEM to test whether the presynaptic G-protein is indeed sensitive to NEM. Figure $9 C$ shows that baclofen depressed the EPSP in the absence of NEM. In the same cell, NEM $(200 \mu \mathrm{M})$ was then applied for $>20 \mathrm{~min}$. Baclofen $(5 \mu \mathrm{M})$ produced no obvious suppression of the EPSP in neurons that had been treated with NEM. The results suggest that NEM blocks presynaptic PTXsensitive G-protein in the DLSN.

\section{DISCUSSION}

\section{Presynaptic facilitation by $5-\mathrm{HT}$}

The present study characterized the facilitatory modulation of excitatory synaptic transmission by exogenously applied 5-HT in brain slices containing the dorsolateral septal nucleus. Under current-clamp conditions, 5-HT increased the amplitude of the EPSP evoked in DLSN neurons by stimulation of the fimbria. Under voltage-clamp conditions, 5-HT also increased the amplitude of the EPSC, indicating that the facilitation of the EPSP is independent of the changes in the membrane potential and conductance at the postsynaptic membrane. Previous studies have shown that 5-HT strongly depresses both fast and slow IPSPs in DLSN neurons (Joëls et al., 1987; Joëls and Gallagher, 1988; Akasu et al., 2000). However, the facilitation of the EPSP is not attributable to the inhibition of IPSPs, because 5-HT directly facilitated the EPSP in the presence of bicuculline and CGP 55845 , blockers for the fast and slow IPSPs, respectively, in DLSN neurons. Because CGP 55845 not only blocks postsynaptic $\mathrm{GABA}_{\mathrm{B}}$ receptors but also blocks presynaptic $\mathrm{GABA}_{\mathrm{B}}$ receptors (Yamada et al., 1999), the facilitatory action of 5-HT is not mediated by the presynaptic $\mathrm{GABA}_{\mathrm{B}}$ receptors located on the glutamatergic synapse. Multiple lines of evidence indicate a presynaptic facilitation of the EPSP by 5-HT. First, 5-HT did not alter the response to exogenously applied L-glutamate, suggesting that 5-HT does not change the sensitivity of glutamate receptors at the postsynaptic neurons. Second, 5-HT increased the frequency of mEPSPs without changing their amplitude. Third, 5-HT depressed paired pulse facilitation of the EPSP. These results suggest that 5-HT increases the release probability of glutamate at presynaptic nerve terminals.

\section{Receptor subtype and signal transduction mechanism}

The subtype of 5-HT receptors mediating the presynaptic facilitation of the EPSP was investigated in DLSN neurons. 5- $\mathrm{HT}_{1 \mathrm{~A}}$ receptors do not seem to mediate the facilitation of the EPSP, because 8-OH-DPAT produced no facilitation but a depression of the amplitude of the EPSP in a subpopulation of DLSN neurons. In a majority of DLSN neurons, 8-OH-DPAT did not produce a significant effect on the EPSP. 5- $\mathrm{HT}_{1 \mathrm{~A}}$ receptor-mediated depression of the EPSP and EPSC has been shown in hippocampal CA1 neurons (Schmitz et al., 1995) and dorsal horn neurons of the spinal cord (Hori et al., 1996). We observed that 5-HT produced an $\sim 52 \%$ increase in the EPSP amplitude in the presence of WAY 100635, a selective $5-\mathrm{HT}_{1 \mathrm{~A}}$ receptor antagonist. $5-\mathrm{HT}_{1 \mathrm{~B}}$ receptors have been shown to mediate the inhibition of the EPSP in several regions of the CNS (Bobker and Williams, 1989; Mooney et al., 1994; Singer et al., 1996; Li and Bayliss, 1998; Hwang and Dun, 1999). However, CP 93129, a selective 5-HT 1 B receptor agonist, did not affect the amplitude of the EPSP. $\alpha$-Methyl-5-HT, a broadspectrum $5-\mathrm{HT}_{2}$ receptor agonist, increased the amplitude of the EPSP. The 5- $\mathrm{HT}_{2 \mathrm{~B}}$ and $5-\mathrm{HT}_{2 \mathrm{C}}$ receptor agonists $\mathrm{BW} 723 \mathrm{C} 86$ and MK 212, respectively, produced no significant change in the amplitude of the EPSP. Ketanserin, a $5-\mathrm{HT}_{2 \mathrm{~A} / 2 \mathrm{C}}$ receptor antagonist, blocked the facilitation of the EPSP induced by 5-HT or $\alpha$-methyl- 


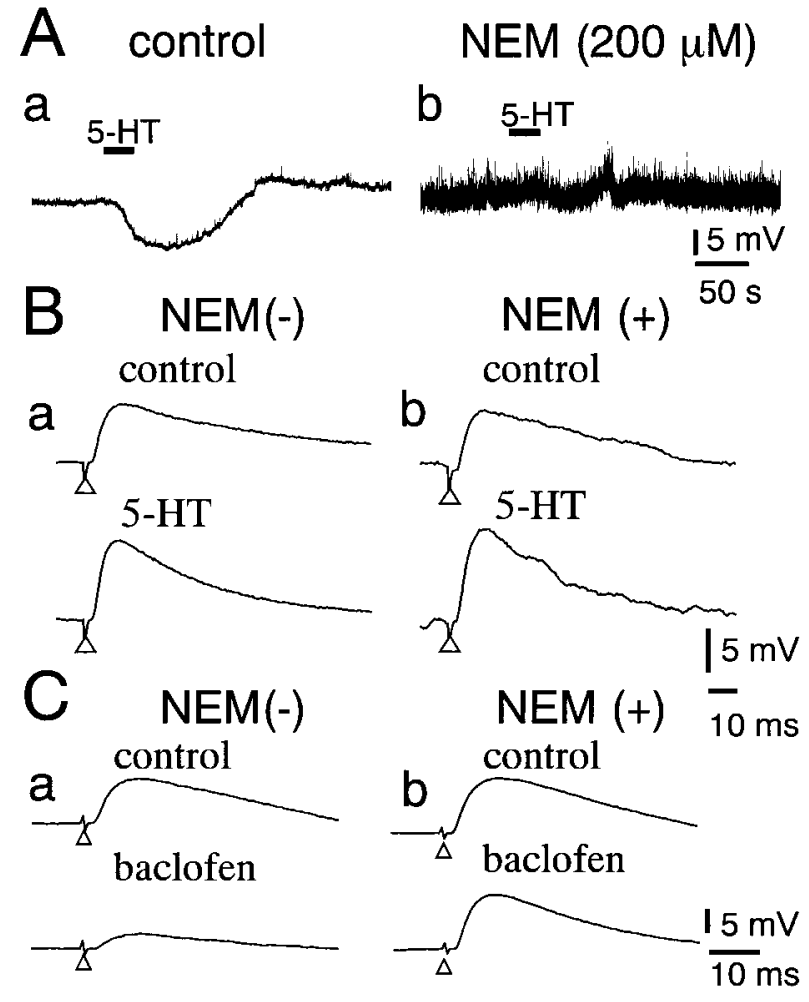

Figure 9. Effects of NEM on the 5-HT-induced facilitation of the EPSP. $A$, Effects of NEM $(200 \mu \mathrm{M})$ on the 5-HT-induced hyperpolarization. Records $a$ and $b$ were taken before and $30 \mathrm{~min}$ after application of NEM $(200 \mu \mathrm{M})$. Solid horizontal bars indicate the period of bath application of 5-HT $(10 \mu \mathrm{M}) . B$, Effects of 5-HT $(10 \mu \mathrm{M})$ on the EPSP in a DLSN neuron before and $30 \mathrm{~min}$ after application of NEM $(200 \mu \mathrm{M})$. Top and bottom traces in $a$ and $b$ were taken before and 5 min after application of 5-HT, respectively. Note that 5-HT increased the amplitude of the EPSP in the presence of NEM. $C$, Effects of NEM $(200 \mu \mathrm{M})$ on the baclofen-induced $(5 \mu \mathrm{M})$ suppression of the EPSP. Records $a$ and $b$ were taken before and 20 min after application of NEM $(200 \mu \mathrm{M})$.

5-HT. In contrast, $N$-desmethylclozapine $(10 \mu \mathrm{M})$, a 5-HT $2 \mathrm{C}$ receptor antagonist, did not antagonize the facilitation of the EPSP induced by $\alpha$-methyl-5-HT (10 $\mu \mathrm{M})$. $\alpha$-Methyl-5-HT also mimicked the effects of 5-HT on mEPSPs and on the paired pulse ratio of the EPSP. These results suggest that presynaptic 5- $\mathrm{HT}_{2 \mathrm{~A}}$ receptors are responsible for the presynaptic facilitation of the glutamate release in the DLSN.

Previous studies have demonstrated that 5-HT stimulates phospholipase $\mathrm{C}$ and phosphatidylinositol turnover through $5-\mathrm{HT}_{2}$ receptors, resulting in the activation of PKC (Hoyer et al., 1994). The present study showed that calphostin C, a selective PKC inhibitor, depressed the 5-HT-induced facilitation of the EPSP. Application of PDBu, an activator of PKC, produced a facilitation of the EPSP. PDBu also markedly increased the frequency of mEPSPs without changing their amplitude. Paired pulse facilitation was markedly depressed by PDBu. Although db-cAMP and forskolin increased the EPSP amplitude, H-89 did not depress the 5-HT-induced facilitation of the EPSP. These results suggest that PKC mediates the 5-HT-induced presynaptic facilitation of the EPSP. The signal transduction process for the 5-HT-induced facilitation of the glutamate release remains to be determined at present. Pharmacological studies suggested the involvement of a PKC pathway in the facilitatory action of 5-HT. A previous study also showed that the presynaptic modulation produced by 5-HT via a PKC pathway was characterized by slow onset and long duration in central neurons (Byrne and Kandel, 1996; Hori et al., 1996). Recently, 5-HT has been shown to enhance spontaneously occurring EPSP by modulating voltage-dependent $\mathrm{Na}^{+}$and $\mathrm{Ca}^{2+}$ channels in neocortical layer $\mathrm{V}$ pyramidal cells (Aghajanian and Marek, 1997). The present study showed, however, that the 5-HTinduced increase in the frequency of the mEPSP was seen in the presence of TTX. It has been shown that phorbol ester itself facilitates transmitter release independently of the external calcium concentration (Malenka et al., 1986; Murphy and Smith, 1987; Shapira et al., 1987). Hori et al. (1999) have demonstrated that phorbol ester causes a presynaptic facilitation of synaptic transmission in the calyx of Held, a giant presynaptic terminal in the rodent brainstem. They proposed that the target of the presynaptic facilitatory effect of phorbol ester was located downstream of the calcium influx and may involve a PKC and Doc2a-Munc13-1 interaction in the transmitter release process. A similar PKCdependent phosphorylation process might be involved in the 5-HTinduced facilitation of the EPSP in DLSN neurons. Molecular cloning has established that all 5-HT receptor subtypes, except $5-\mathrm{HT}_{3}$ receptors, belong to the superfamily of the G-proteincoupled receptors (Hoyer et al., 1994). It has been shown that presynaptic $\mathrm{GABA}_{\mathrm{B}}$ receptors on glutamatergic nerve terminals couple to a G-protein that is sensitive to NEM, an uncoupler of receptors from PTX-sensitive G-protein (Nakajima et al., 1990; Shapiro et al., 1994). In the DLSN, activation of presynaptic $\mathrm{GABA}_{\mathrm{B}}$ receptors inhibits the EPSC (Yamada et al., 1999). The present study showed that application of NEM blocked the baclofen-induced depression of the EPSP. These results suggested that NEM can block presynaptic G-protein that mediates the presynaptic inhibition of the EPSP in the DLSN. In contrast, 5-HT caused a typical facilitation of the EPSP in DLSN neurons treated with NEM. We suggest that the $5-\mathrm{HT}_{2 \mathrm{~A}}$ receptor is coupled to a PTX-insensitive G-protein, mostly the $\mathrm{Gq} / \mathrm{G}_{11}$ class (Alexander et al., 2001), or directly activates PKC in DLSN neurons.

\section{Physiological and pathophysiological roles of 5-HT}

Under a current-clamp condition, 5-HT ceased spontaneous firing of action potentials by producing hyperpolarization, and it facilitated the excitatory synaptic transmission. This results in an enhancement of the signal-to-noise ratio in DLSN neurons. The 5-HT-induced facilitation of the excitatory synaptic transmission is long-lasting even after washout of 5-HT, suggesting that 5-HT may contribute to the plasticity of synaptic transmission, such as long-term potentiation. It has been shown that the effect of 5-HT on synaptic transmission is use-dependent (Montarole et al., 1986). We observed that repeated application of 5-HT produced a facilitation of the EPSP in some DLSN neurons but showed no significant facilitation of the EPSP during antecedent 5-HT application.

The $5-\mathrm{HT}_{2 \mathrm{~A}}$ receptor has been implicated in numerous emotional disorders, including depression, anxiety, psychosis, and schizophrenia (for review, see Naughton et al., 2000). It is hypothesized that abnormal neurotransmission at $5-\mathrm{HT}_{2}$ receptors is involved in the pathophysiology of schizophrenia (Laruelle et al., 1993). Typical antipsychotic drugs, such as clozapine, olanzapine, and risperidone, have a strong therapeutic effect on schizophrenia as a combination blockers for $\mathrm{D}_{1} / \mathrm{D}_{2}$ and $5-\mathrm{HT}_{2 \mathrm{~A}}$ receptors (Leonard, 1997). As is the case for the limbic system, the lateral septum is known to participate in a variety of physiological and behavioral processes related to emotions, such as aggressiveness, fear, and other socially and sexually related behaviors (Lisciotto et al., 1990). The facilitation of excitatory synaptic trans- 
mission between the hippocampus and the lateral septum may be involved in 5- $\mathrm{HT}_{2 \mathrm{~A}}$ receptor-mediated improvement of emotional and mental disorders.

\section{REFERENCES}

Aghajanian GK, Marek GJ (1997) Serotonin induces excitatory postsynaptic potentials in apical dendrites of neocortical pyramidal cells. Neuropharmacology 36:589-599.

Akasu T, Hasuo H, Goto M (2000) 5-Hydroxytryptamine modulates synaptic transmission in the hippocamposeptal pathway. In: Slow synaptic responses and modulation (Kuba $\mathrm{K}$, Higashida $\mathrm{H}$, Brown DA, Yoshioka T, eds), pp 403-409. Tokyo: Springer.

Alexander SPH, Mathie A, Peters JA, eds (2001) TiPS nomenclature supplement, Vol 12. New York: Elsevier.

Alonso JR, Frotscher M (1989) Organization of the septal region in the rat brain: a Golgi/EM study of lateral septal neurons. J Comp Neurol 286:472-487.

Beck SG (1992) 5-Hydroxytryptamine increases excitability of CA1 hippocampal pyramidal cells. Synapse 10:334-340.

Biegon A, Rainbow TC, McEwen BS (1982) Quantitative autoradiography of serotonin receptors in the rat brain. Brain Res 242:197-204.

Bobker DH, Williams JT (1989) Serotonin agonists inhibit synaptic potentials in the rat locus ceruleus in vitro via 5-hydroxytryptamine ${ }_{1 \mathrm{~A}}$ and

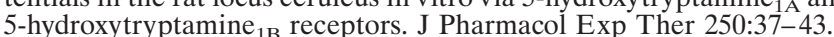

Byrne JH, Kandel ER (1996) Presynaptic facilitation revisited: state and time dependence. J Neurosci 16:425-435.

Chijiwa T, Mishima A, Hagiwara M, Sano M, Hayashi K, Inoue T, Naito K, Toshioka T, Hidaka H (1990) Inhibition of forskolin-induced neurite outgrowth and protein phosphorylation by a newly synthesized selective inhibitor of cyclic AMP-dependent protein kinase, $N-[2-(p-$ bromocinnamylamino)ethyl]-5-isoquinolinesulfonamide (H-89), of PC12D pheochromocytoma cells. J Biol Chem 265:5267-5272.

Crunelli V, Segal M (1985) An electrophysiological study of neurones in the median raphe and their projections to septum and hippocampus. Neuroscience 15:47-60.

Debanne D, Guérineau NC, Gähwiler BH, Thompson SM (1996) Paired-pulse facilitation and depression at unitary synapses in rat hippocampus: quantal fluctuation affects subsequent release. J Physiol (Lond) 491:163-176.

DeFrance JF, Kitai ST, McCrea RA, Kocsis JD, Hatada K (1973) Excitatory effects of 5-hydroxytryptamine in the hippocampal-septal circuit. Brain Res 58:245-250.

Gall C, Moore RY (1984) Distribution of enkephalin, substance P, tyrosine hydroxylase, and 5-hydroxytryptamine immunoreactivity in the septal region of the rat. J Comp Neurol 225:212-227.

Gallagher JP, Zheng F, Hasuo H, Shinnick-Gallagher P (1995) Activities of neurons within the rat dorsolateral septal nucleus (DLSN). Prog Neurobiol 45:373-395.

Gustafson EL, Durkin MM, Bard JA, Zgombick J, Branchek TA (1996) A receptor autoradiographic and in situ hybridization analysis of the distribution of the 5-ht7 receptor in rat brain. $\mathrm{Br} \mathrm{J}$ Pharmacol 117:657-666.

Hasuo H, Akasu T (2001) Activation of inhibitory pathways suppresses the induction of long-term potentiation in neurons of the rat lateral septal nucleus. Neuroscience 105:343-352.

Hori Y, Endo K, Takahashi T (1996) Long-lasting synaptic facilitation induced by serotonin in superficial dorsal horn neurones of the rat spinal cord. J Physiol (Lond) 492:867-876.

Hori T, Takai Y, Takahashi T (1999) Presynaptic mechanism for phorbol ester-induced synaptic potentiation. J Neurosci 19:7262-7267.

Hoyer D, Clarke DE, Fozard JR, Hartig PR, Martin GR, Mylecharane EJ, Saxena PR, Humphrey PPA (1994) VII. International union of pharmacology classification of receptors for 5-hydroxytryptamine (serotonin). Pharmacol Rev 46:157-203.

Hwang LL, Dun NJ (1999) Serotonin modulates synaptic transmission in immature rat ventrolateral medulla neurons. Neuroscience 91:959-970.

Isaacson JS (1998) GABA $_{\mathrm{B}}$ receptor-mediated modulation of presynaptic currents and excitatory transmission at a fast central synapse. J Neurophysiol 80:1571-1576.

Jakab RL, Leranth C (1995) Septum. In: The rat nervous system, Ed 2 (Paxinos G, ed), pp 405-442. San Diego: Academic.

Joëls M, Gallagher JP (1988) Actions of serotonin recorded intracellularly in rat dorsal lateral septal neurons. Synapse 2:45-53.

Joëls M, Shinnick-Gallagher P, Gallagher JP (1987) Effect of serotonin and serotonin analogues on passive membrane properties of lateral septal neurons in vitro. Brain Res 417:99-107.

Katz B (1969) The release of neural transmitter substances. Liverpool: Liverpool UP.

Kobayashi E, Nakano H, Morimoto M, Tamaoki T (1989) Calphostin C (UCN-1028C), a novel microbial compound, is a highly potent and specific inhibitor of protein kinase C. Biochem Biophys Res Commun 159:548-553.
Köhler C, Chan-Palay V, Steinbusch H (1982) The distribution and origin of serotonin-containing fibers in the septal area: a combined immunohistochemical and fluorescent retrograde tracing study in the rat. J Comp Neurol 209:91-111.

Laruelle M, Abi-Dargham A, Casanova MF, Toti R, Weinberger DR, Kleinman JE (1993) Selective abnormalities of prefrontal serotonergic receptors in schizophrenia: a postmortem study. Arch Gen Psychiatry 50:810-818

Leonard BE (1997) Fundamentals of psychopharmacology, Ed 2. New York: Wiley.

Li Y-W, Bayliss DA (1998) Presynaptic inhibition by $5-\mathrm{HT}_{1 \mathrm{~B}}$ receptors of glutamatergic synaptic inputs onto serotonergic caudal raphe neurons in rat. J Physiol (Lond) 510:121-134.

Lisciotto CA, DeBold JF, Haney M, Miczek KA (1990) Implants of testosterone into the septal forebrain activate aggressive behavior in male mice. Aggress Behav 16:249-258.

Malenka RC, Madison DV, Nicoll RA (1986) Potentiation of synaptic transmission in the hippocampus by phorbol esters. Nature 321:175-177.

Manabe T, Wyllie DJA, Perkel DJ, Nicoll RA (1993) Modulation of synaptic transmission and long-term potentiation: effects on paired pulse facilitation and EPSC variance in the CA1 region of the hippocampus. J Neurophysiol 70:1451-1459.

Marcinkiewicz M, Vergé D, Gozlan H, Pichat L, Hamon M (1984) Autoradiographic evidence for the heterogeneity of $5-\mathrm{HT}_{1}$ sites in the rat brain. Brain Res 291:159-163.

Montarole PG, Goelet P, Castellucci VF, Morgan J, Kandel ER, Schacher S (1986) A critical period for macromolecular synthesis in long-term heterosynaptic facilitation in Aplysia. Science 234:1249-1254.

Mooney RD, Shi MY, Rhoades RW (1994) Modulation of retinotectal transmission by presynaptic 5-HT1B receptors in the superior colliculus of the adult hamster. J Neurophysiol 72:3-13.

Morales M, Battenberg E, Bloom FE (1998) Distribution of neurons expressing immunoreactivity for the $5 \mathrm{HT}_{3}$ receptor subtype in the rat brain and spinal cord. J Comp Neurol 385:385-401.

Murphy RL, Smith ME (1987) Effects of diacylglycerol and phorbol ester on acetylcholine release and action at the neuromuscular junction in mice. Br J Pharmacol 90:327-334.

Nakajima T, Irisawa H, Giles W (1990) N-Ethylmaleimide uncouples muscarinic receptors from acetylcholine-sensitive potassium channels in bullfrog atrium. J Gen Physiol 96:887-903.

Naughton M, Mulrooney JB, Leonard BE (2000) A review of the role of serotonin receptors in psychiatric disorders. Hum Psychopharmacol Clin Exp 15:397-415.

Pazos A, Palacios JM (1985) Quantitative autoradiographic mapping of serotonin receptors in the rat brain. I. Serotonin-1 receptors. Brain Res 346:205-230.

Pazos A, Cortés R, Palacios JM (1985) Quantitative autoradiographic mapping of serotonin receptors in the rat brain. II. Serotonin-2 receptors. Brain Res 346:231-249.

Schmitz D, Empson RM, Heinemann U (1995) Serotonin and 8-OHDPAT reduce excitatory transmission in rat hippocampal area CA1 via reduction in presumed presynaptic $\mathrm{Ca}^{2+}$ entry. Brain Res 701:249-254

Segal M (1980) The action of serotonin in the rat hippocampal slice preparation. J Physiol (Lond) 303:423-439.

Shapira R, Silberberg SD, Ginsburg S, Rahamimoff R (1987) Activation of protein kinase $\mathrm{C}$ augments evoked transmitter release. Nature 325:58-60.

Shapiro MS, Wollmuth LP, Hille B (1994) Modulation of $\mathrm{Ca}^{2+}$ channels by PTX-sensitive G-proteins is blocked by $N$-ethylmaleimide in rat sympathetic neurons. J Neurosci 14:7109-7116.

Singer JH, Bellingham MC, Berger AJ (1996) Presynaptic inhibition of glutamatergic synaptic transmission to rat motoneurons by serotonin. J Neurophysiol 76:799-807.

Stevens DR, Gallagher JP, Shinnick-Gallagher P (1984) Intracellular recordings from rat dorsolateral septal neurons, in vitro. Brain Res 305:353-356.

Thompson SM, Capogna M, Scanziani M (1993) Presynaptic inhibition in the hippocampus. Trends Neurosci 16:222-227.

Vergé D, Daval G, Marcinkiewicz M, Patey A, El Mestikawy S, Gozlan H, Hamon M (1986) Quantitative autoradiography of multiple 5-HT receptor subtypes in the brain of control or 5, 7-dihydroxytryptaminetreated rats. J Neurosci 6:3474-3482.

Waeber C, Sebben M, Nieoullon A, Bockaert J, Dumuis A (1994) Regional distribution and ontogeny of $5-\mathrm{HT}_{4}$ binding sites in rodent brain Neuropharmacology 33:527-541.

Yamada K, Yu B, Gallagher JP (1999) Different subtypes of GABA receptors are present at pre- and postsynaptic site within the rat dorsolateral septal nucleus. J Neurophysiol 81:2875-2883.

Yamada K, Hasuo H, Ishimatsu M, Akasu T (2001) Characterization of outward currents induced by 5-HT in neurons of rat dorsolateral septal nucleus. J Neurophysiol 85:1453-1460. 